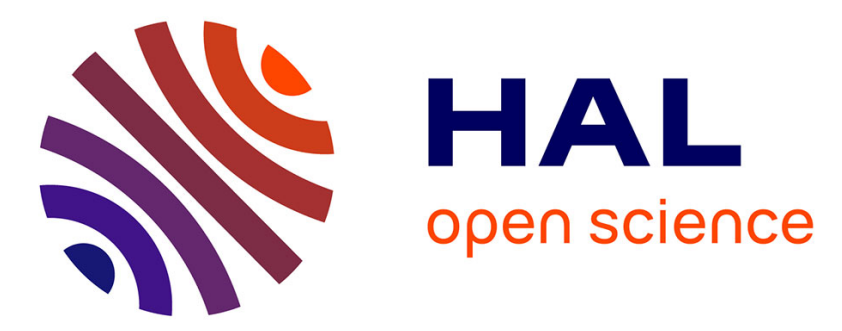

\title{
Post-bacterial infection chronic fatigue syndrome is not a latent infection
}

\author{
Clea Melenotte, Michel Drancourt, Jean Pierre Gorvel, Jean-Louis Mege, \\ Didier Raoult
}

\section{- To cite this version:}

Clea Melenotte, Michel Drancourt, Jean Pierre Gorvel, Jean-Louis Mege, Didier Raoult. Post-bacterial infection chronic fatigue syndrome is not a latent infection. Médecine et Maladies Infectieuses, 2019, 49 (2), pp.140-149. 10.1016/j.medmal.2019.01.006 . hal-02262541

\section{HAL Id: hal-02262541 \\ https: / hal-amu.archives-ouvertes.fr/hal-02262541}

Submitted on 22 Oct 2021

HAL is a multi-disciplinary open access archive for the deposit and dissemination of scientific research documents, whether they are published or not. The documents may come from teaching and research institutions in France or abroad, or from public or private research centers.
L'archive ouverte pluridisciplinaire HAL, est destinée au dépôt et à la diffusion de documents scientifiques de niveau recherche, publiés ou non, émanant des établissements d'enseignement et de recherche français ou étrangers, des laboratoires publics ou privés.

\section{(c) (1) $\$$}

Distributed under a Creative Commons Attribution - NonCommercial| 4.0 International 


\title{
Post-bacterial infection chronic fatigue syndrome is not a latent
}

\author{
infection
}

Le syndrome de fatigue chronique post infection bactérienne n'est

\section{pas une infection latente}

Cléa Melenotte $^{1}$, Michel Drancourt ${ }^{1}$, Jean Pierre Gorvel ${ }^{2}$, Jean Louis Mège ${ }^{1}$, Didier Raoult ${ }^{1}$

(1) Aix Marseille Univ, IRD, APHM, MEPHI, IHU-Méditerranée Infection, Marseille, France

(2) Aix Marseille Univ, CNRS, INSERM, CIML, Marseille, France.

Corresponding author: melenotteclea@gmail.com

Full postal address:

URMITE,

IHU - Méditerranée Infection

19-21 Boulevard Jean Moulin

13005 Marseille, France

Phone: (33) 491835699

Fax: (33) 491387772

Keywords: Lyme disease, latent infection, post-infectious chronic fatigue syndrome

Mots clés : maladie de Lyme, infection latente, syndrome de fatigue chronique post-infectieux 


\section{ABSTRACT}

Post-infectious chronic fatigue syndrome is a public health problem. Etiologies and physiopathological mechanisms are unknown. Some viruses are known to be involved in post-infectious chronic fatigue syndrome, but the role of bacterial infection is still questionned, especially in cases of post-treatment Lyme disease syndrome where subjective symptoms are regularly attributed to the presence of the dormant bacterium without scientific evidence.

However, the medical experience of recalcitrant infections, relapses, and reactivations questions the role of "dormant bacteria" in asymptomatic latent infections as well as in subjective symptoms. We summarized scientific literature data on post-bacterial infection chronic fatigue syndrome, the role of dormant bacteria in latent infections, and bacterial asymptomatic carriage. Subjective symptoms described in postinfectious chronic fatigue syndromes are still misunderstood and there is no evidence suggesting that such symptoms could be related to dormant bacterial infection or carriage of viable bacteria. Psychological trauma may be part of these subjective symptoms. Post-infectious chronic fatigue syndrome could nonetheless be due to unknown microorganisms. Antibiotic treatment is not required for latent infections, except for latent syphilis and latent tuberculosis infections to prevent, after the primary infection, progression to the secondary or tertiary stage of the disease. 


\section{Résumé}

Le syndrome de fatigue chronique post-infectieux représente un enjeu de santé publique. Ses étiologies et mécanismes pathophysiologiques restent inconnus. Certains virus sont impliqués dans le syndrome de fatigue chronique post-infectieux, mais le rôle de l'infection bactérienne est encore remis en question notamment dans le cadre du «Lyme tardif post-thérapeutique » lors duquel les symptômes subjectifs sont régulièrement attribués à la présence de la bactérie dormante, sans preuve scientifique.

Toutefois, l'expérience médicale des infections réfractaires au traitement, des rechutes et des réactivations met en doute le rôle de la «bactérie dormante » dans les infections latentes asymptomatiques ainsi qu'en cas de symptômes subjectifs. Nous résumons les données scientifiques issues de la littérature sur le syndrome de fatigue chronique post infection bactérienne, le rôle des bactéries dormantes dans les infections latentes et le portage bactérien asymptomatique. Les symptômes subjectifs décrits en cas de syndromes de fatigue chronique post-infectieux restent peu compris et aucune donnée ne suggère que ces symptômes peuvent être liés à une infection bactérienne dormante ou au portage de bactéries viables. Un traumatisme psychologique pourrait en partie expliquer ces symptômes subjectifs. Le syndrome de fatigue chronique post-infectieux pourrait néanmoins être dû à des micro-organismes inconnus. Aucun traitement antibiotique n'est requis en cas d'infections latentes, à l'exception d'une syphylis latente ou d'une infection tuberculeuse latente afin de prévenir la progression vers les stades secondaires et tertiaires de la maladie, après l'infection primaire. 


\section{Introduction}

Chronic fatigue syndrome is defined by unexplained disability syndrome and a combinaison of non-specific subjective symptoms including fatigue, headache, musculoskeletal pain, neurocognitive disorders, sleeping disorders, mood disorders, and even respiratory tract disorders. Chronic fatigue syndrome represents a major public health problem, but its etiologies remain poorly understood. Post-infectious chronic fatigue syndrome has been reported after viral infections such as Epstein-Barr virus infection, Chikungunya virus infection, and hepatitis A and B infections $[1,2,3]$. Regarding bacterial infections, post-infectious chronic fatigue syndrome may be suspected after brucellosis, Q fever caused by Coxiella burnetii, and Lyme disease caused by Borrelia burgdorferi group (Borreliae). However, no evidence of a progressive infection can explain chronic fatigue syndrome (no clinical or biological inflammatory syndrome, no evidence of bacterial multiplication, and no evidence of antibiotic effectiveness). Post-infectious chronic fatigue syndrome therefore remains a crucial and unsolved issue. The question currently raised is whether latent infection could be responsible for subjective syndrome, as told in the post-treatment Lyme disease syndrome.

However, the medical experience of recalcitrant infections, relapses, and reactivations observed in cases of bone and joint infections even decades after the primary infection, underlines that some bacteria could persist in a dormant stage. These dormant bacteria remain quiescent and viable, without any clinical manifestation. Several factors can promote reactivation such as immunosuppression and pregnancy, but no reactivation factors can sometimes be identified. Some bacterial infections occur in several stages, with latency periods in-between some stages. This is the case for Lyme disease, tuberculosis, and syphilis. The primary infection is self-limiting, but if left untreated the disease can 
quiescently progress to secondary or tertiary manifestations. Finally, the identification of pathogenic bacteria in asymptomatic and healthy individuals, as asymptomatic carriage, led us to re-interrogate Koch's postulates.

To find out whether these latent infections, dormant bacteria, or asymptomatic carriages may have a role in post-infectious chronic fatigue syndrome, we performed a literature review. We searched Medline and Googlescholar databases for references with no language restriction and no restriction of publication time nor status, with the following keywords: dormant bacteria, latent infection, post-infectious chronic fatigue syndrome, chronic fatigue syndrome, asymptomatic carriage, post-treatment lyme disease syndrome, post-Q fever fatigue syndrome, latent tuberculosis, Mycobacterium tuberculosis, Brucella spp., Tropheryma whipplei, Bartonella spp., Staphylococcus aureus. A total of 119 references were included in the final qualitative synthesis.

\section{Post-bacterial infection chronic fatigue syndrome}

\section{Coxiella burnetii: the $Q$ fever fatigue syndrome}

First described in 1992, the Q fever fatigue syndrome (QFS) is a health challenge as it is responsible for impaired quality of life and absenteeism $[4,5]$. QFS is characterized by subjective symptoms for at least six months after acute Q fever. It is responsible for significant disability in daily living and it is not associated with objective symptoms nor organic lesions $[6,7,8]$. The diagnosis should rule out other somatic and psychiatric etiologies of chronic fatigue syndrome. QFS also does not correlate with the anti-C. burnetii phase I IgG levels, which are insufficient and erroneous to conclude to the persistence or lack of persistence of the infection. 
In the Netherlands, after the 2007-2011 epidemiological outbreaks, QFS developped in 20\% of patients who had been diagnosed with acute Q fever as compared with $4 \%$ of healthy controls [5]. In Australia, QFS developped in 28\% of patients who had been diagnosed with acute Q fever versus $0 \%$ of controls [9]. Pentillas et al. provided the first broad description of QFS in Australia, but their report can be questioned as they included patients presenting with objective symptoms (diarrhea, swollen superficial lymph node) [10]. Just like post-treatment Lyme disease syndrome (PTLDS), the persistence of living microbes has been suggested to be involved in QFS, but never confirmed [10]. A fundamental and dangerous confusion may thus be observed between latent infections and QFS. This confusion leads to misdiagnosing C. burnetii persistent latent infection as illustrated by the fatal case recently reported by Sudocheva et al.: a 19-year-old man was diagnosed with post-Q fever fatigue syndrome and died from disseminated $C$. burnetii infection 10 years after acute Q fever infection [11, 12]. C. burnetii was identified by immunohistochemistry (IHC) and polymerase chain reaction (PCR) targeting the COM1 and IS1111 sequences in all post-mortem investigated organs [11]. Marmion et al. also reported two cases of patients misdiagnosed with chronic fatigue syndrome instead of persistent $C$. burnetii endocarditis (one fatal case) $[9,13]$. These three cases argue in favor of long-term latent and asymptomatic C. burnetii infection. This infection is different from QFS as it only affects patients presenting with subjective signs and symptoms, with no detected living bacteria. Experimental studies on tissues distinguished living bacteria from dead bacteria using fluorescence in situ hybridization targeting the bacterial ribonucleic acid [14]. As C. burnetii was not isolated from these blood samples in case of QFS, persistent $C$. burnetii cell components are probably residues of the original heavy seeding during bacteremia rather than a renewed production of viable bacteria [8]. The long-term persistence of non-viable in situ or circulating C. burnetii cell components including antigens or DNA is the sole biological finding currently correlating with these subjective 
symptoms. The circulation of these bacterial cell components could result in an altered cell immunity and in an altered cytokine production [13, $15,16,17]$. The subsequent ongoing production of pro-inflammatory cytokines could then be responsible for fatigue. Patients presenting with QFS were described as differing in the frequency of HLA-DRB1*11 carriage and the $2 / 2$ genotype of the IFN $\gamma$ intron 1 microsatellite when compared with controls [18]. In addition, cytokine release pattern of peripheral blood monocyte cells of QFS patients was reported as aberrant with an increased IL-6 release, a decreased level of IL2 release, and an increased INFY and CXCL10 production [19].

Just like PTLDS, it is unknown whether QFS is a direct consequence of the non-viable or viable bacteria or if its origin is psychological.

Predictors of QFS are contradictory, and factors such as female sex and young adult have been associated with QFS [8]. The severity of the acute illness as well as preexisting health problems and hospitalization have been reported as QFS predictors [20, 21].

\section{Borrelia burgdorferi and post-treatment Lyme disease syndrome}

Post-treatment Lyme disease syndrome (PTLDS) is characterized by the late onset of musculoskeletal symptoms and antibiotic treatment failures. PTLDS is estimated to affect $10 \%$ to $20 \%$ of patients treated with antibiotics effective against Lyme disease [22, 23]. PTLDS is a public and political challenge as compared with $C$. burnetii infection, but few studies have been conducted to identify B. burgdorferi cell components or to understand the physiological and immune mechanisms involved in PTLDS [24]. Picha et al. performed a study with B. burgdorferi-infected patients, and identified B. burgdorferi DNA up to six months after the administration of an effective antimicrobial treatment. However, this result does not indicate the presence of living bacteria, and all patients with a positive B. burgdorferi PCR did not present with subjective symptoms 
$[25,26]$. Autoimmune diseases are believed to be involved in patients diagnosed with PTLDS. Maccallini et al. hypothetized that such patients exhibited auto-immunity against $\gamma$-enolase, the neuron-specific isoenzyme of the glycolytic enzyme enolase [27].

Cabello et al. explained that in the absence of sterilizing immunity a strong antibody response was observed. They suggested that $B$. burgdorferi is located in a niche where it could be protected from the adaptive immune response [28]. The extracellular matrix, rich in collagen such as tendon and ligaments, was suspected to be the niche of B. burgdorferi in mice [28]. Crossland et al. recently identified persistent nonviable Borrelia in the central nervous system, joint-associated tissues, and urinary bladder of rhesus macaques following doxycycline therapy [29]. Hodzic et al. demonstrated that after ceftriaxone therapy in a mouse model, B. burgdorferi could not be cultured from tissues while low copy number of specific DNA sequences could be detected two, four, and eight months after treatment completion [30].

Interestingly, Iyer et al. demonstrated in vitro that B. burgdorferi could not be cultured three days after ceftriaxone antibiotic treatment, but positive B. burgdorferi DNA was detected up to 56 days after antibiotic treament [26]. These results are at odds with experimental data reported by Caskey et al. showing the doxycycline inability to kill quiescent B. burdgorferi, which newly developed after antimicrobial therapy [31]. The lack of studies in humans does not allow scientific support for the responsibility of quiescent B. burgdorferi or dormant bacteria in PTLDS.

\section{Brucella spp. and post-infectious fatigue syndrome}

Chronic fatigue syndrome after Brucella infection has been reported in patients with poor health, musculoskeletal pain, depression, or anxiety without any infectious focus of the disease [32]. However, the definition and description of persistent subjective symptoms after brucellosis is 
often mistaken with chronic brucellosis. Historically, antigen therapy was suggested to patients presenting with chronic brucellosis following antibiotic therapy $[33,34,35]$. The term "post-brucellosis fatigue syndrome" could be more appropriate to differentiate subjective symptoms without detectable organic lesions following infection from chronic persistent Brucella infection.

Some studies focused on post-brucellosis disease. The persistent detection of Brucella spp. DNA after an effective antibiotic therapy was initially related to relapses. Castano et al. recently identified the presence of Brucella spp. DNA in the blood and serum of patients presenting with persistent focalized infection, with non-focal disease and with subjective symptoms. This finding was even observed in the group of asymptomatic subjects with a history of brucellosis, but not in the control group [32]. The authors reported that the proportion of individuals with Brucella melitensis DNA was significantly higher in symptomatic non-focal disease patients (patients with subjective symptoms and without identified focus) than in asymptomatic subjects [32]. Brucella abortus has been widely used to study chronic fatigue syndrome in animal models. An impaired mouse running activity has been described when animals were inoculated with $B$. abortus antigens [36]. Potential oxidative stress and immunological activation as assessed by an increase in tumor necrosis factor alpha are involved in chronic fatigue syndrome induced by $B$. abortus [37].

Whether for Brucella spp., C. burnetii, or B. burgdorferi, the persistence of bacterial DNA copies in blood samples remains poorly understood. We do not know if these DNA sequences are associated with subjective symptoms and the expression of viable dormant bateria. 


\section{Dormant bacteria and latent infection: a reversible aliveness}

In 1944 Joseph Bigger led the founding stone of the concept of "dormant bacteria", with a microbiological definition. He observed that penicillin lysed a growing population of Staphyloccocus spp. but only a small proportion, although not resistant to antibiotics and not in a fission stage, survived [38]. This data suggested that penicillin was only effective in dividing bacteria. "Dormant bacteria" are characterized by a nongrowing and non-replicating stage, by viability (but unable to grow on usual culture media), and by tolerability to stress including stress-induced

antibiotics [39, 40]. Consequently, they could be responsible for antibiotic treatment failure to eradicate the infection. At the "dormant" stage, bacteria are also non-virulent and bypass the innate immune system response. These bacteria could return to growth and normal activity when original conditions are restored [39].

\section{Staphylococcus aureus bone and joint infection}

Since the description of Staphylococcus aureus as a "dormant" bacterium, mechanisms used to achieve its intracellular persistence have been partially identified. S. aureus small colony variant (SCV) is a quiescent metabolic state related to persistence, recurrence, and antibiotic resistance [40-42]. Small colonies are also distinguished from usual S. aureus colonies on agar plates by their decreased pigmentation and reduced hemolysis [40-42]. S. aureus SCVs are then characterized by a low metabolic activity. Proctor et al. showed that $S$. aureus SCVs settled in an intracellular niche and that $25 \%$ of the initial inoculum switched to SCVs [43, 44].

In humans, S. aureus SCVs were recovered from abscess, bone and joint, blood, catheters, heart, and respiratory tract. All presented auxotrophic defects accounting for their low metabolic activities [45]. Non-professional phagocytic cells such as endothelial cells, epithelial cells, fibrobasts, osteoblasts, and keratinocytes were identified as host cells for intracellular persistence of $S$. aureus SCVs [42]. In vitro, keratinocytes and 
endothelial cells infected with $S$. aureus SCVs did not present any sign of damaged cells unlike cells infected with the usual $S$. aureus which underwent cell apoptosis or necrosis [42]. This data supports the role of these cells as latent niches for S. aureus infection.

\section{Latent bacterial infection}

\section{a. Syphilis}

Treponema pallidum is responsible for syphilis and is characterized by its ability to invade the human body and escape the immune system. It is also characterized by a latent stage following the secondary stage and preceding the tertiary stage of the infection [46]. Early latent syphilis is defined by a positive serology without clinical symptoms. Late latency may start one or two years after exposure and may last up to several decades. It is estimated that $15-40 \%$ of untreated individuals develop tertiary syphilis characterized by cardiac, neurological, skin, and bone involvement with destructive syphilitic gumma, hemiparesis, aphasia, aortitis, aortic aneurysm, and congestive heart failure or coronary disease [46]. As a global worldwide re-emerging disease, latent $T$. pallidum infection is still challenging physicians because of two critical complications. In immunocompromised hosts, malignant syphilis has been described as a severe cutaneous complication of syphilis in AIDS patients, and we recently observed neurological syphilis involvement in HIV-infected patients with low CD4 level $\left(<350 / \mathrm{mm}^{3}\right)$. These reports demonstrated that immunosuppression is a factor promoting awakening of the latent form [47, 48]. Pregnant women presenting with latent syphilis can transmit the infection in utero leading to recent dramatic outbreaks of congenital syphilis in Australia and the United States [49-51, 52].

The detection of T. pallidum DNA in patients with latent stage of the disease was only observed in blood and ear scraping [53]. Only former animal studies aimed to understand T. pallidum quiescent surviving. One century ago, Pearce and Brown described the rabbit's large and 
indurated lymph nodes (inguinal, popliteal, submental, auricular, axillary, and large flanck) as the latent niches of the bacterium [54]. Inoculation of the emulsion of resected asymptomatic lymph nodes induced the development of syphilis in previously uninfected animals [54]. In another experimental work, Collart et al. showed that corticosteroids reactivated latent syphilis in two of 12 rabbits [55]. During this latent stage, the authors pointed out the morphological transformation of Treponema [55]. T. pallidum is supposed to survive extracellulary, in areas rich in connective tissues and relatively inaccessible to circulating immune cells (tunica albuginea, tunica media of the aorta, testes) [55]. Cerebrospinal fluid and lymphoid sites act as reservoirs for spirochetes, and maintain the disease in a quiescent state. The latent stage is characterized by the absence of symptoms and the reactivation may be promoted by immunosuppression or other hitherto unknown factors.

\section{b. Lyme disease}

Borrelia burgdorferi infection is characterized by symptom-free stages and several years may go by between the early localized and late disseminated stages [56]. There is no documented case of bacterial presence at the latent stage. Reports rather focus on descriptions of the secondary or tertiary stage of the infection $[57,58]$. Several animal models tried to identify the persistent niche of $B$. burgdorferi but most of these models focused on explaining PTLDS in mice, dogs, and macaques, and provided evidence of persistent bacteria by immunofluorescence and PCR after antibiotic therapy [29]. As previously discussed, the presence of B. burgdorferi DNA does not indicate bacterial viability.

As B. burgdorferi is probably present at a latent stage before the tertiary stage of the infection, its niche has not been identified. Although speculative works using mathematical models studied dormant properties of B. burgdorferi in vitro and in vivo, only migratory birds have been reported as able to carry B. burgdorferi at a latent stage for several months [59, 31]. Moreover, immunosuppression has not been described as 
favoring the reactivation of B. burgdorferi, nor has it been described as influencing the acute phase of the infection [60]. This was anecdotically described for B. miyamotoi reactivation in a patient presenting with follicular lymphoma treated with chemotherapy [61]. Finally, evidence for latent Lyme disease reactivation in immunocompromised patients is scarce.

\section{c. Tuberculosis}

Mycobacterium tuberculosis is a global health challenge, with 10.4 milion new cases diagnosed in 2016 and 1.3 million deaths [62]. It has been estimated that one third of the global population carries latent $M$. tuberculosis infection - representing an enormous reservoir of potential tuberculosis cases - after initial infection usually occurring during childhood [63]. The infection is almost kept under control by the immune system and leads to disease in only $10 \%$ of cases [63]. Hundreds of million of tuberculosis reactivation cases are expected in future decades, representing a public health challenge [62]. The term "latent tuberculosis" was coined by Clemens von Pirquet (the inventor of the tuberculin skin test [TST]) in 1907. He described children with a positive TST presenting without any clinical symptoms [64]. The current definition of latent tuberculosis combines a positive TST or positive interferon gamma release assay without clinical nor active radiological signs of the disease. Patients presenting with latent tuberculosis cannot transmit the disease but are subject to reactivation, with an estimated $2 \%$ to $23 \%$ of lifetime risk in developped countries [65].

Reactivation of M. tuberculosis is triggered when the host's immune response is weakened or suppressed. Patients with high risk of reactivation have HIV co-infection, lymphoma, leukemia, neck cancer, or underwent transplantation or chemotherapy, or received TNF-alpha inhibitor 
treatment $[66,67,68,69]$. Patients with a moderate risk of reactivation are patients with diabetes mellitus and patients treated with systemic glucocorticoids [70, 71]. The success of $M$. tuberculosis is first based on its capacity to avoid the microbicidal activity of macrophages [72, 73]. The reduction of MHC II expression by macrophages prevents the recognition of infected macrophages by CD4+ T lymphocytes and the activation of the adaptive immune response especially. In addition, M. tuberculosis inhibits the phagolysosome fusion avoiding the vacuole acidification and clearance of the ingested microorganism. It has been demonstrated that $M$. tuberculosis further prevents host cell apoptosis by enhancing the release of the membrane-bound TNFR2 receptors and by upregulating the expression of Mcl-1 (Bc12 family protein) [74]. In response to environmental stress, M. tuberculosis mycobacteria shut down and close tight causing thickening and decreased permeability of the cell wall [74]. M. tuberculosis turns down its own central metabolism and survives for a long time in a dormant non-replicating stage. Interestingly, the toxin-antitoxin system is involved in the persistence of Mycobacterium sp. in a dormant non-replicating stage [74]. At a physiological stage, the long-lived "toxin" protein is neutralized by the short-lived "antitoxin" protein. However, at the dormant stage $M$. tuberculosis represses the expression of the antitoxin protein, which results in the accumulation of the "toxin" protein [74]. The toxin protein, as a ribonuclease, cleaves free and ribosomal-bound single-stranded mRNA, inhibiting protein synthesis and bacterial growth [74]. A group of proteins called the resuscitation promoting factors (encoded by rpf genes) also induce $M$. tuberculosis out of the dormant stage [75]. When the stress agent is removed, $r p f$ genes are activated, proteins are produced, and the bacterium is able to re-enter a replicative phase [75]. The wellorganized granuloma confers a confined environment for the survival of the bacterium and Mycobacterium can be released as a serpentine cord in the granuloma, a morphological presentation which is not recognized and not phagocyted by macrophages [75]. 
The cellular niches of M. tuberculosis have been revisited at the beginning of this century by Hernandez-Pando et al.. They identified $M$. tuberculosis DNA in macrophages and in non-professional phagocytic type II pneumocytes, endothelial cells, and fibroblasts [63]. Neyrolles et al. observed non-replicating $M$. tuberculosis mycobacteria within adipocytes where they exhibited increased resistance to isoniazid and a diminished resistance to pyrazinamide. This result is consistent with the hydrophilic property of isoniazid [76]. Furthermore, Ayyappan et al. showed that in experimentally infected rabbits, M. tuberculosis modulated differently the adipocyte signalling according to the latent or active infections [77].

Nonetheless, animal models tried to reproduce latent $M$. tuberculosis infection, but none was truly contributory and representative as "latency" was drug-induced $[78,79]$.

\section{d. Rickettsiosis, the Brill-Zinsser disease}

Rickettsia prowazekii is responsible for epidemic typhus and is transmitted by body lice. It has deeply marked the history of medicine, war, famine, and migration [80]. In addition to its typical presentation including abrupt fever, rashes, and headaches, recurrent presentations of epidemic typhus have been reported such as Brill-Zinsser disease [80]. First described in 1934, Brill-Zinsser disease is unrelated to louse infestation but also presents as fever, headache, and cutaneous rash [81]. The reactivation of $R$. prowazekii can occur even 40 years after the acute infection. Bacteremia can be detected and IgG antibodies serum reactivation assessed, with no detectable IgM antibodies, demonstrating the reactivation of the infection [82]. It has been hypothetized that after the initial contamination, the bacterium spreads via the lymphatic route and blood towards endothelial cells [80]. Some authors showed that Rickettsia spp. could be found in lymph nodes years after the acute infection, 
suggesting this lymphoid organ as a niche for bacterial survival and dormancy [83]. In mice, adipocytes were demonstrated to be the specific cell type for $R$. prowazekii dormancy [84]. Latent typhus infection was identified in two animal models: mice and cotton rats. $R$. prowazekii was reactivated using dexamethasone, which induced an anti-inflammatory effect on the host's innate immune response [82, 83]. However, the mechanism of $R$. prowazekii dormancy and reactivation in humans has not been established.

\section{e. Brucella spp.}

Brucella spp. are able to induce latent infections [86, 87]. Brucella spp. reactivation as a gall bladder infection has been reported 28 years after primary infection in a non-endemic region [86, 87]. Immunossupression such as chemotherapy (cyclophosphamide, vincristine, methotrexate, 5fluorouracil, etoposide, doxorubicin, and cisplatin and dexamethasone), transplantation, and anecdotically during pregnancy, has been reported [88-90]. Although the latency niche has not been well-established in humans, in animals bacteria were isolated from vaginal secretion and milk of asymptomatic sheep up to three years after the infection of the flock [91]. Rats born from Brucella abortus-infected mothers have been reported as latent carriers of Brucella. Cervical lymph nodes are described as an initial efficient trap for Brucella, and were also identified as a potential reservoir niche for chronic pathogen persistence [92]. Brucella can survive for a while in the host cell macrophages and dendritic plasmacytoid cells. It highlights their ability to induce chronic and life-long infections. Just like C. burnetii and M. tuberculosis, Brucella spp. can prevent apoptosis of the macrophage, through Bcl2A1 upregulation [93]. Brucella thus persists in tissues and induces granulomatous inflammation. The latter inflammation restricts bacterial replication but is insufficient to kill the bacterium [94]. In addition to macrophages, dendritic cells and microglia, non-phagocytic cells such as fibroblasts, epithelial cells, osteoblastic cell lines, trophoblasts, and astrocytes have 
been suggested as niches [94]. Jacob et al. have shown that Brucella spontaneous smooth small colony variants were characterized by a less effective clearance from spleen and liver in experimentally infected mice [95].

\section{f. Coxiella burnetii}

The latent $C$. burnetii infection stage has been suspected after relapses were observed in patients presenting with an apparent $\mathrm{Q}$ fever recovery [96-98]. The placenta was described as a latent niche for C. burnetii, insofar as the bacterium was isolated from the placenta of women with a history of $\mathrm{Q}$ fever, but without clinical manifestations of the disease [99-101]. The latent presentation could be reactivated by immunosuppression or pregnancy and could infect placenta, heart valve, vascular, bones, or liver.

In the 1940s, it was demonstrated that $C$. burnetii persisted in animals after an initial clinical or subclinical infection. Its persistence was first explored in guinea pigs where the rickettsial agent of American and Australian Q fever was present in various organs up to 110 days after the primary infection and after defervescence [102]. The experimental works of Sidwell described the latent infection as an unapparent infection in which host equilibrium is established. C. burnetii reactivation was described with deep infectious focus after whole body irradiation, or after repeated injections of corticosteroids in guinea pigs and, to a lesser extent, in mice three months after the primary C. burnetii infection [96, 103]. In a study inoculating $C$. burnetii in pregnant sheep (early stage of pregnancy), the bacterium was detected up to 13 weeks in the bone marrow, spleen, liver, kidney, and in placenta just before parturition and at 20 weeks post delivery [17, 104]. This data argues in favor of the reactivation of a cryptic infection and of the existence of latent niches for C. burnetii. 
The biological form of the persistent organism is unknown. It was hypothesized that $C$. burnetii survives in macrophages as resistant small-cell variants. In a mouse model, Bechah et al. demonstrated the persistence of $C$. burnetii in abdominal inguinal and dorsal adipose tissues and in macrophages up to four months after the primary infection [105]. C. burnetii inhibits the fusion with lysosome in the late phagosome of cultured adipocytes, and inhibits apoptosis [105]. Further clinical investigations are required to identify the organ of latent $C$. burnetii infection and the biological form of the persistent organism.

All infectious agents mentioned in the present article are able to induce primary infection and persistent focalized infection. The primary infection could be separated from the persistent focalized infection by a free phase, during which no clinical symptoms are observed. This phase could be called the latency phase. Table 1 summarizes the site of latency and the evidence for bacterial survival without clinical symptoms in humans.

\section{Bacterial carriage without symptoms}

1. Bartonella species

Unlike bacterial DNA detection in asymptomatic patients with a history of infectious diseases, Bartonella spp. were isolated from the blood of asymptomatic donors. Bacteria were identified by culture and real-time PCR from the blood of $3.2 \%$ of asymptomatic healthy blood donors [106, 107]. Bartonella spp. could therefore be transmitted during transfusion [106, 107].

\section{Tropheryma whipplei in asymptomatic carriers}


Whipple's disease was first considered a chronic digestive disease and was then considered an acute pneumonia or epidemic fever [108, 109, 110]. Although the typical presentation includes diarrhea, weight loss, abdominal pain, and arthralgia, T. whipplei asymptomatic carriage in middle-aged men remains intriguing [111]. Two per cent to $44 \%$ of the population carries the bacterium in stools without clinical symptoms, but the worldwide annual incidence of the disease is only estimated at 12 new cases [112]. Immunosuppression has been shown to promote the activation of the disease as reported by various authors, with almost 50\% of patients presenting with T. whipplei infection treated with immunosuppressive therapy before Whipple's disease diagnosis [113, 114, 115]. Genetic background, corticosteroids, and tumor necrosis factor inhibitors $(10 \%)$ lead to a more rapid clinical progression and a clear onset $[115,116]$.

\section{What is the rationale for treatment?}

The international scientific community only recommends antibiotic treatment for two latent infections: latent syphilis and latent tuberculosis infection.

\section{Treatment of latent syphilis to prevent late relapse and complications}

Regarding the dramatic consequences of tertiary syphilis and the resurgence of congenital syphilis in developped countries, the Centers for Disease Control and Prevention (CDC) and the World Health Organization (WHO) both recommend treating this latent infection (Table 2) [117, $118]$

\section{Treatment of latent tuberculosis infection to prevent relapses in high priority groups}


Patients with positive TST or positive interferon-gamma assay should undergo medical evaluation to rule out active tuberculosis. When active tuberculosis has been ruled out, the CDC and WHO recommend initiating an antibiotic therapy in patients belonging to high priority groups (Table 2) [119].

\section{No evidence of antibiotic efficacy on subjective symptoms}

\section{a) $Q$ fever chronic fatigue}

Some studies have supported a biopsychological etiology for Q fever syndrome [8]. Although the benefits of the antibiotic therapy were controversially reported in the literature, a randomized study recently concluded on the issue. Cognitive behavioral therapy was effective in reducing fatigue severity in Q fever syndrome patients whereas prolonged therapy with doxycycline was not [6].

b) PTLDS

On the basis of the heterogeneous accuracy of serological testing for Lyme disease and the variety of subjective symptoms wrongly attributed to Lyme disease, no antibiotic treatment should be proposed in the absence of active infection confirmation (positive microbiological test and detection of an organic lesion).

In addition, a recent study performed by Goodlet et al. reported that oral or intravenous antibiotic therapies in cases of post-treatment Lyme disease symptoms were associated with an increased morbidity within 90 days [22]. 


\section{Conclusion}

Post-infectious chronic fatigue syndrome is characterized by subjective symptoms without evidence of living bacteria as the disease is not associated with relapses. Conversely, latent infection could be defined as an asymptomatic disease prone to reactivation in which the microorganisms are likely to be dormant. Furthermore, asymptomatic carriage is not associated by definition with subjective symptoms.

The subjective symptoms described in post-bacterial infection chronic fatigue syndrome are still misunderstood and no evidence is currently available to demonstrate that such symptoms could be related to a dormant bacterial infection or to carriage of viable bacteria. Other etiologies including psychological trauma may be part of these subjective symptoms. Post-infectious chronic fatigue syndrome could nonetheless be due to yet unknown microorganisms. 


\section{References}

1. Duvignaud A, Fianu A, Bertolotti A, Jaubert J, Michault A, Poubeau P, et al. Rheumatism and chronic fatigue, the two facets of postchikungunya disease: the TELECHIK cohort study on Reunion island. Epidemiol Infect. 2018 Apr;146(5):633-41.

2. Jason LA, Katz BZ, Shiraishi Y, Mears CJ, Im Y, Taylor R. Predictors of Post-Infectious Chronic Fatigue Syndrome in Adolescents. Health Psychol Behav Med. 2014 Jan 1;2(1):41-51.

3. Berelowitz GJ, Burgess AP, Thanabalasingham T, Murray-Lyon IM, Wright DJ. Post-hepatitis syndrome revisited. J Viral Hepat. 1995;2(3):133-8.

4. Keijmel SP, Delsing CE, Bleijenberg G, van der Meer JWM, Donders RT, Leclercq M, et al. Effectiveness of Long-term Doxycycline Treatment and Cognitive-Behavioral Therapy on Fatigue Severity in Patients with Q Fever Fatigue Syndrome (Qure Study): A Randomized Controlled Trial. Clin Infect Dis Off Publ Infect Dis Soc Am. 2017 15;64(8):998-1005.

5. Keijmel SP, Delsing CE, Sprong T, Bleijenberg G, van der Meer JWM, Knoop H, et al. The Qure study: Q fever fatigue syndrome-response to treatment; a randomized placebo-controlled trial. BMC Infect Dis. 2013 Mar 27;13:157.

6. Keijmel SP, Delsing CE, Bleijenberg G, van der Meer JWM, Donders RT, Leclercq M, et al. Effectiveness of Long-term Doxycycline Treatment and Cognitive-Behavioral Therapy on Fatigue Severity in Patients with Q Fever Fatigue Syndrome (Qure Study): A Randomized Controlled Trial. Clin Infect Dis Off Publ Infect Dis Soc Am. 2017 15;64(8):998-1005.

7. $\quad$ Parker NR, Barralet JH, Bell AM. Q fever. Lancet Lond Engl. 2006 Feb 25;367(9511):679-88.

8. Morroy G, Keijmel SP, Delsing CE, Bleijenberg G, Langendam M, Timen A, et al. Fatigue following Acute Q-Fever: A Systematic Literature Review. PloS One. 2016;11(5):e0155884.

9. Marmion BP, Sukocheva O, Storm PA, Lockhart M, Turra M, Kok T, et al. Q fever: persistence of antigenic non-viable cell residues of Coxiella burnetii in the host--implications for post Q fever infection fatigue syndrome and other chronic sequelae. QJM Mon J Assoc Physicians. 2009 Oct;102(10):673-84.

10. Penttila IA, Harris RJ, Storm P, Haynes D, Worswick DA, Marmion BP. Cytokine dysregulation in the post-Q-fever fatigue syndrome. QJM Mon J Assoc Physicians. 1998 Aug;91(8):549-60.

11. Sukocheva OA, Manavis J, Kok T-W, Turra M, Izzo A, Blumbergs P, et al. Coxiella burnetii dormancy in a fatal ten-year multisystem dysfunctional illness: case report. BMC Infect Dis. 2016 Apr 18;16:165.

12. Raoult D. Q Fever: Confusion Between Chronic Infection and Chronic Fatigue. Clin Infect Dis Off Publ Infect Dis Soc Am. 2017 Sep 15;65(6):1054-5.

13. Harris RJ, Storm PA, Lloyd A, Arens M, Marmion BP. Long-term persistence of Coxiella burnetii in the host after primary Q fever. Epidemiol Infect. 2000 Jun;124(3):543-9.

14. Melenotte C, Million M, Audoly G, Gorse A, Dutronc H, Roland G, et al. B-cell non-Hodgkin lymphoma linked to Coxiella burnetii. Blood. 2016 Jan 7;127(1):113-21. 
15. Keijmel SP, Raijmakers RPH, Bleeker-Rovers CP, van der Meer JWM, Netea MG, Schoffelen T, et al. Altered interferon- $\gamma$ response in patients with Q-fever fatigue syndrome. J Infect. 2016 Apr;72(4):478-85.

16. Kato K, Arashima Y, Asai S, Furuya Y, Yoshida Y, Murakami M, et al. Detection of Coxiella burnetii specific DNA in blood samples from Japanese patients with chronic nonspecific symptoms by nested polymerase chain reaction. FEMS Immunol Med Microbiol. 1998 Jun;21(2):139-44.

17. Harris RJ, Storm PA, Lloyd A, Arens M, Marmion BP. Long-term persistence of Coxiella burnetii in the host after primary Q fever. Epidemiol Infect. 2000 Jun;124(3):543-9.

18. Helbig K, Harris R, Ayres J, Dunckley H, Lloyd A, Robson J, et al. Immune response genes in the post-Q-fever fatigue syndrome, Q fever endocarditis and uncomplicated acute primary Q fever. QJM Mon J Assoc Physicians. 2005 Aug;98(8):565-74.

19. Raijmakers RPH, Jansen AFM, Keijmel SP, Schoffelen T, Scholzen A, van der Meer JWM, et al. Interferon- $\gamma$ and CXCL10 responses related to complaints in patients with Q fever fatigue syndrome. Eur J Clin Microbiol Infect Dis Off Publ Eur Soc Clin Microbiol. 2018 Jul;37(7):1385-91.

20. Strauss B, Löschau M, Seidel T, Stallmach A, Thomas A. Are fatigue symptoms and chronic fatigue syndrome following Q fever infection related to psychosocial variables? J Psychosom Res. 2012 Apr;72(4):300-4.

21. Morroy G, Peters JB, van Nieuwenhof M, Bor HHJ, Hautvast JLA, van der Hoek W, et al. The health status of Q-fever patients after long-term follow-up. BMC Infect Dis. 2011 Apr 18;11:97.

22. Goodlet KJ, Fairman KA. Adverse Events Associated with Antibiotics and Intravenous Therapies for Post-Lyme Disease Syndrome in a Commercially Insured Sample. Clin Infect Dis Off Publ Infect Dis Soc Am. 2018 Apr 17;

23. Cairns V, Godwin J. Post-Lyme borreliosis syndrome: a meta-analysis of reported symptoms. Int J Epidemiol. 2005 Dec 1;34(6):1340-5.

24. Cervantes J. Doctor says you are cured, but you still feel the pain. Borrelia DNA persistence in Lyme disease. Microbes Infect. 2017 Oct;19(9-10):459-63.

25. Pícha D, Moravcová L, Vaňousová D, Hercogová J, Blechová Z. DNA persistence after treatment of Lyme borreliosis. Folia Microbiol (Praha). 2014 Mar;59(2):115-25.

26. Iyer R, Mukherjee P, Wang K, Simons J, Wormser GP, Schwartz I. Detection of Borrelia burgdorferi nucleic acids after antibiotic treatment does not confirm viability. J Clin Microbiol. 2013 Mar;51(3):857-62.

27. Maccallini P, Bonin S, Trevisan G. Autoimmunity against a glycolytic enzyme as a possible cause for persistent symptoms in Lyme disease. Med Hypotheses. 2018 Jan;110:1-8.

28. Cabello FC, Godfrey HP, Newman SA. Hidden in plain sight: Borrelia burgdorferi and the extracellular matrix. Trends Microbiol. 2007 Aug;15(8):350-4.

29. Crossland NA, Alvarez X, Embers ME. Late Disseminated Lyme Disease: Associated Pathology and Spirochete Persistence Posttreatment in Rhesus Macaques. Am J Pathol. 2018 Mar;188(3):672-82. 
30. Hodzic E, Imai D, Feng S, Barthold SW. Resurgence of persisting non-cultivable Borrelia burgdorferi following antibiotic treatment in mice. PloS One. 2014;9(1):e86907.

31. Caskey JR, Embers ME. Persister Development by Borrelia burgdorferi Populations In Vitro. Antimicrob Agents Chemother. 2015 Oct;59(10):6288-95.

32. Castaño MJ, Solera J. Chronic brucellosis and persistence of Brucella melitensis DNA. J Clin Microbiol. 2009 Jul;47(7):2084-9.

33. Boura P, Skendros P, Kountouras J, Zacharioudaki E, Tsapas T. Effect of bacterial extracts on the immunologic profile in chronic relapsing brucellosis patients. Int J Immunopathol Pharmacol. 1999 Aug;12(2):103-11.

34. Roux J. [Antigen therapy in chronic brucellosis]. Dev Biol Stand. 1976;31:227-9.

35. Benning HM. Chronic brucellosis; success of treatment with brucellin. J Am Med Assoc. 1946 Feb 9;130:320-5.

36. Ottenweller JE, Natelson BH, Gause WC, Carroll KK, Beldowicz D, Zhou XD, et al. Mouse running activity is lowered by Brucella abortus treatment: a potential model to study chronic fatigue. Physiol Behav. 1998 Mar;63(5):795-801.

37. Gupta A, Vij G, Chopra K. Possible role of oxidative stress and immunological activation in mouse model of chronic fatigue syndrome and its attenuation by olive extract. J Neuroimmunol. 2010 Sep 14;226(1-2):3-7.

38. BIGGER J. Treatment of Staphyloeoeeal Infections with Penicillin by Intermittent Sterilisation. Lancet. 1944;497-500.

39. Kell D, Potgieter M, Pretorius E. Individuality, phenotypic differentiation, dormancy and "persistence" in culturable bacterial systems: commonalities shared by environmental, laboratory, and clinical microbiology. F1000Research. 2015;4:179.

40. Barer MR. Viable but non-culturable and dormant bacteria: time to resolve an oxymoron and a misnomer? J Med Microbiol. 1997 Aug;46(8):629-31.

41. Kell DB, Kenny LC. A Dormant Microbial Component in the Development of Preeclampsia. Front Med. 2016;3:60.

42. Proctor RA, von Eiff C, Kahl BC, Becker K, McNamara P, Herrmann M, et al. Small colony variants: a pathogenic form of bacteria that facilitates persistent and recurrent infections. Nat Rev Microbiol. 2006 Apr;4(4):295-305.

43. Proctor RA, van Langevelde P, Kristjansson M, Maslow JN, Arbeit RD. Persistent and relapsing infections associated with smallcolony variants of Staphylococcus aureus. Clin Infect Dis Off Publ Infect Dis Soc Am. 1995 Jan;20(1):95-102.

44. Proctor RA, Kriegeskorte A, Kahl BC, Becker K, Löffler B, Peters G. Staphylococcus aureus Small Colony Variants (SCVs): a road map for the metabolic pathways involved in persistent infections. Front Cell Infect Microbiol. 2014;4:99.

45. Kahl BC. Small colony variants (SCVs) of Staphylococcus aureus--a bacterial survival strategy. Infect Genet Evol J Mol Epidemiol Evol Genet Infect Dis. 2014 Jan;21:515-22.

46. Peeling RW, Mabey D, Kamb ML, Chen X-S, Radolf JD, Benzaken AS. Syphilis. Nat Rev Dis Primer. 2017 Oct 12;3:17073.

47. dos Santos TR, de Castro IJ, Dahia MMB, de Azevedo MCVM, da Silva G a. R, Motta RN, et al. Malignant syphilis in an AIDS patient. Infection. 2015 Apr;43(2):231-6.

48. Hobbs E, Vera JH, Marks M, Barritt AW, Ridha BH, Lawrence D. Neurosyphilis in patients with HIV. Pract Neurol. 2018 Jun;18(3):211-8. 
49. Cooper JM, Porter M, Bazan JA, Nicholson LM, Sánchez PJ. The Re-Emergence of Congenital Syphilis in Ohio. Pediatr Infect Dis J. 2018 Mar 21;

50. Plotzker RE, Murphy RD, Stoltey JE. Congenital Syphilis Prevention: Strategies, Evidence, and Future Directions. Sex Transm Dis. 2018 Apr 5;

51. Nogrady B. Sixth child dies from congenital syphilis in northern Australia. BMJ. 2018 19;360:k1272.

52. DiOrio D, Kroeger K, Ross A. Social Vulnerability in Congenital Syphilis Case Mothers: Qualitative Assessment of Cases in Indiana, 2014-2016. Sex Transm Dis. 2018 Jan 4;

53. Castro R, Prieto E, Aguas MJ, Manata MJ, Botas J, Santo I, et al. Detection of Treponema pallidum sp pallidum DNA in latent syphilis. Int J STD AIDS. 2007 Dec;18(12):842-5.

54. Pearce L, Brown WH. A STUDY OF THE RELATION OF TREPONEMA PALLIDUM TO LYMPHOID TISSUES IN EXPERIMENTAL SYPHILIS. J Exp Med. 1922 Jan 1;35(1):39-62.

55. Collart P, Borel LJ, Durel P. SIGNIFICANCE OF SPIRAL ORGANISMS FOUND, AFTER TREATMENT, IN LATE HUMAN AND EXPERIMENTAL SYPHILIS. Br J Vener Dis. 1964 Jun;40:81-9.

56. Albert S, Schulze J, Riegel H, Brade V. Lyme arthritis in a 12-year-old patient after a latency period of 5 years. Infection. 1999;27(4-5):286-8.

57. Pfister HW, Preac-Mursic V, Wilske B, Einhäupl KM, Weinberger K. Latent Lyme neuroborreliosis: presence of Borrelia burgdorferi in the cerebrospinal fluid without concurrent inflammatory signs. Neurology. 1989 Aug;39(8):1118-20.

58. Fand R. Pruritus in latent Lyme disease. Conn Med. 2009 Aug;73(7):445.

59. Gylfe A, Bergström S, Lundström J, Olsen B. Reactivation of Borrelia infection in birds. Nature. 2000 Feb 17;403(6771):724-5.

60. Fürst B, Glatz M, Kerl H, Müllegger RR. The impact of immunosuppression on erythema migrans. A retrospective study of clinical presentation, response to treatment and production of Borrelia antibodies in 33 patients. Clin Exp Dermatol. 2006 Jul;31(4):509-14.

61. Boden K, Lobenstein S, Hermann B, Margos G, Fingerle V. Borrelia miyamotoi-Associated Neuroborreliosis in Immunocompromised Person. Emerg Infect Dis. 2016;22(9):1617-20.

62. WHO, Global tuberculosis report, 2017.

63. Hernández-Pando R, Jeyanathan M, Mengistu G, Aguilar D, Orozco H, Harboe M, et al. Persistence of DNA from Mycobacterium tuberculosis in superficially normal lung tissue during latent infection. Lancet Lond Engl. 2000 Dec 23;356(9248):2133-8.

64. Daniel TM. The history of tuberculosis. Respir Med. 2006 Nov;100(11):1862-70.

65. Tufariello JM, Chan J, Flynn JL. Latent tuberculosis: mechanisms of host and bacillus that contribute to persistent infection. Lancet Infect Dis. 2003 Sep;3(9):578-90.

66. Wood R, Maartens G, Lombard CJ. Risk factors for developing tuberculosis in HIV-1-infected adults from communities with a low or very high incidence of tuberculosis. J Acquir Immune Defic Syndr 1999. 2000 Jan 1;23(1):75-80.

67. Cheng MP, Abou Chakra CN, Yansouni CP, Cnossen S, Shrier I, Menzies D, et al. Risk of Active Tuberculosis in Patients with Cancer: 
A Systematic Review and Meta-Analysis. Clin Infect Dis Off Publ Infect Dis Soc Am. 2017 01;64(5):635-44.

68. Aguado JM, Herrero JA, Gavaldá J, Torre-Cisneros J, Blanes M, Rufí G, et al. Clinical presentation and outcome of tuberculosis in kidney, liver, and heart transplant recipients in Spain. Spanish Transplantation Infection Study Group, GESITRA. Transplantation. 1997 May 15;63(9):1278-86.

69. Keane J, Gershon S, Wise RP, Mirabile-Levens E, Kasznica J, Schwieterman WD, et al. Tuberculosis associated with infliximab, a tumor necrosis factor alpha-neutralizing agent. N Engl J Med. 2001 Oct 11;345(15):1098-104.

70. Jick SS, Lieberman ES, Rahman MU, Choi HK. Glucocorticoid use, other associated factors, and the risk of tuberculosis. Arthritis Rheum. 2006 Feb 15;55(1):19-26.

71. Lee M-R, Huang Y-P, Kuo Y-T, Luo C-H, Shih Y-J, Shu C-C, et al. Diabetes Mellitus and Latent Tuberculosis Infection: A Systemic Review and Metaanalysis. Clin Infect Dis Off Publ Infect Dis Soc Am. 2017 15;64(6):719-27.

72. Neyrolles O. Bacterial pathogenesis: A sand grain in antigen processing. Nat Microbiol. 2016 Dec 5;2:16234.

73. Pires D, Marques J, Pombo JP, Carmo N, Bettencourt P, Neyrolles O, et al. Role of Cathepsins in Mycobacterium tuberculosis Survival in Human Macrophages. Sci Rep. 2016 Aug 30;6:32247.

74. Peddireddy V, Doddam SN, Ahmed N. Mycobacterial Dormancy Systems and Host Responses in Tuberculosis. Front Immunol. 2017;8:84.

75. Gupta A, Kaul A, Tsolaki AG, Kishore U, Bhakta S. Mycobacterium tuberculosis: immune evasion, latency and reactivation. Immunobiology. 2012 Mar;217(3):363-74.

76. Neyrolles O, Hernández-Pando R, Pietri-Rouxel F, Fornès P, Tailleux L, Barrios Payán JA, et al. Is adipose tissue a place for Mycobacterium tuberculosis persistence? PloS One. 2006 Dec 20;1:e43.

77. Ayyappan JP, Vinnard C, Subbian S, Nagajyothi JF. Effect of Mycobacterium tuberculosis infection on adipocyte physiology. Microbes Infect. 2018 Feb;20(2):81-8.

78. McCune RM, Feldmann FM, Lambert HP, McDermott W. Microbial persistence. I. The capacity of tubercle bacilli to survive sterilization in mouse tissues. J Exp Med. 1966 Mar 1;123(3):445-68.

79. McCune RM, Feldmann FM, McDermott W. Microbial persistence. II. Characteristics of the sterile state of tubercle bacilli. J Exp Med. 1966 Mar 1;123(3):469-86.

80. Bechah Y, Capo C, Mege J-L, Raoult D. Epidemic typhus. Lancet Infect Dis. 2008 Jul;8(7):417-26.

81. Murray ES, Psorn T, Djakovic P, Sielski S, Broz V, Ljupsa F, et al. Brill's disease. IV. Study of 26 cases in Yugoslavia. Am J Public Health Nations Health. 1951 Nov;41(11 Pt 1):1359-69.

82. Stein A, Purgus R, Olmer M, Raoult D. Brill-Zinsser disease in France. Lancet Lond Engl. 1999 Jun 5;353(9168):1936.

83. Lutwick LI. Brill-Zinsser disease. Lancet Lond Engl. 2001 Apr 14;357(9263):1198-200.

84. Bechah Y, Paddock CD, Capo C, Mege J-L, Raoult D. Adipose tissue serves as a reservoir for recrudescent Rickettsia prowazekii infection in a mouse model. PloS One. 2010 Jan 1;5(1):e8547. 
85. Ignatovich VF. Experimental study of latency in typhus infection. J Hyg Epidemiol Microbiol Immunol. 1973;17(2):176-83.

86. Meneses A, Epaulard O, Maurin M, Gressin R, Pavese P, Brion J-P, et al. [Brucella bacteremia reactivation 70 years after the primary infection]. Med Mal Infect. 2010 Apr;40(4):238-40.

87. Ögredici Ö, Erb S, Langer I, Pilo P, Kerner A, Haack HG, et al. Brucellosis reactivation after 28 years. Emerg Infect Dis. 2010 Dec;16(12):2021-2.

88. Sari R, Buyukberber N, Sevinc A, Bayindir Y, Buyukberber S. Brucellosis in the etiology of febrile neutropenia: case report. J Chemother Florence Italy. 2002 Feb;14(1):88-91.

89. Metan G, Sardan YC, Hascelik G. Brucellosis in all patients with febrile neutropenia. Leuk Lymphoma. 2006 May;47(5):954-6.

90. Ertem M, Kürekçi AE, Aysev D, Unal E, Ikincioğullari A. Brucellosis transmitted by bone marrow transplantation. Bone Marrow Transplant. 2000 Jul;26(2):225-6.

91. Tittarelli M, Di Ventura M, De Massis F, Scacchia M, Giovannini A, Nannini D, et al. The persistence of Brucella melitensis in experimentally infected ewes through three reproductive cycles. J Vet Med B Infect Dis Vet Public Health. 2005 Nov;52(9):403-9.

92. von Bargen K, Gagnaire A, Arce-Gorvel V, de Bovis B, Baudimont F, Chasson L, et al. Cervical Lymph Nodes as a Selective Niche for Brucella during Oral Infections. PloS One. 2014;10(4):e0121790.

93. Gross A, Terraza A, Ouahrani-Bettache S, Liautard JP, Dornand J. In vitro Brucella suis infection prevents the programmed cell death of human monocytic cells. Infect Immun. 2000 Jan;68(1):342-51.

94. Atluri VL, Xavier MN, de Jong MF, den Hartigh AB, Tsolis RM. Interactions of the human pathogenic Brucella species with their hosts. Annu Rev Microbiol. 2011;65:523-41.

95. Jacob J, Hort GM, Overhoff P, Mielke MEA. In vitro and in vivo characterization of smooth small colony variants of Brucella abortus S19. Microbes Infect. 2006 Feb;8(2):363-71.

96. Sidwell RW, Thorpe BD, Gebhardt LP. STUDIES OF LATENT Q FEVER INFECTIONS. II. EFFECTS OF MULTIPLE CORTISONE INJECTIONS. Am J Hyg. 1964 May;79:320-7.

97. Beck MD, Bell JA. Q fever studies in Southern California; an epidemiological study of 300 cases. Public Health Rep Wash DC 1896. 1949 Jan 14;64(2):41-56.

98. Bertrand L, Roux J. [Isolation of a strain of Coxiella burnetii on the occasion of a relapse of human Q fever]. Ann Inst Pasteur. 1955 Jul;89(1):131-2.

99. Syrucek L. Q fever in North-West Bohemia 1954-1958. J Hyg Epidemiol Microbiol Immunol. 1959;3:465-71.

100. Babudieri B. Studies on the microscopic slide-agglutination test for Q fever. Bull World Health Organ. 1958;19(6):981-94.

101. Babudieri B, Moscovici C. Experimental and natural infection of birds by Coxiella burneti. Nature. 1952 Feb 2;169(4292):195-6.

102. Parker RR, Kohls GM. American Q Fever: The Occurrence of Rickettsia diaporica in Amblyomma americanum in Eastern Texas. Public Health Rep 1896-1970. 1943;58(41):1510.

103. Sidwell RW, Thorpe BD, Gebhardt LP. STUDIES ON LATENT Q FEVER INFECTIONS. I. EFFECTS OF WHOLE BODY X-IRRADIATION 
UPON LATENTLY INFECTED GUINEA PIGS, WHITE MICE AND DEER MICE. Am J Hyg. 1964 Jan;79:113-24.

104. Abinanti FR, Marmion BP. Protective or neutralizing antibody in Q fever. Am J Hyg. 1957 Sep;66(2):173-95.

105. Bechah Y, Verneau J, Ben Amara A, Barry AO, Lépolard C, Achard V, et al. Persistence of Coxiella burnetii, the agent of Q fever, in murine adipose tissue. PloS One. 2014;9(5):e97503.

106. Diniz PPV de P, Velho PENF, Pitassi LHU, Drummond MR, Lania BG, Barjas-Castro ML, et al. Risk Factors for Bartonella species Infection in Blood Donors from Southeast Brazil. PLoS Negl Trop Dis. 2016 Mar;10(3):e0004509.

107. Pitassi LHU, de Paiva Diniz PPV, Scorpio DG, Drummond MR, Lania BG, Barjas-Castro ML, et al. Bartonella spp. bacteremia in blood donors from Campinas, Brazil. PLoS Negl Trop Dis. 2015 Jan;9(1):e0003467.

108. Lagier J-C, Papazian L, Fenollar F, Edouard S, Melenotte C, Laroumagne S, et al. Tropheryma whipplei DNA in bronchoalveolar lavage samples: a case control study. Clin Microbiol Infect Off Publ Eur Soc Clin Microbiol Infect Dis. 2016 Oct;22(10):875-9.

109. Lagier J-C, Fenollar F, Raoult D. Acute infections caused by Tropheryma whipplei. Future Microbiol. 2017;12:247-54.

110. Bassene H, Mediannikov O, Socolovschi C, Ratmanov P, Keita AK, Sokhna C, et al. Tropheryma whipplei as a Cause of Epidemic Fever, Senegal, 2010-2012. Emerg Infect Dis. 2016;22(7):1229-334.

111. Hujoel IA, Johnson DH, Lebwohl B, Leffler D, Kupfer S, Wu T-T, et al. Tropheryma whipplei Infection (Whipple Disease) in the USA. Dig Dis Sci. 2018 Mar 23;

112. Dutly F, Altwegg M. Whipple’s disease and “Tropheryma whippelii.” Clin Microbiol Rev. 2001 Jul;14(3):561-83.

113. Marth T. Systematic review: Whipple's disease (Tropheryma whipplei infection) and its unmasking by tumour necrosis factor inhibitors. Aliment Pharmacol Ther. 2015 Apr;41(8):709-24.

114. Marth T. Tropheryma whipplei , Immunosuppression and Whipple's Disease: From a Low-Pathogenic, Environmental Infectious Organism to a Rare, Multifaceted Inflammatory Complex. Dig Dis Basel Switz. 2015;33(2):190-9.

115. Lagier J-C, Lepidi H, Raoult D, Fenollar F. Systemic Tropheryma whipplei: clinical presentation of 142 patients with infections diagnosed or confirmed in a reference center. Medicine (Baltimore). 2010 Sep;89(5):337-45.

116. Guérin A, Kerner G, Marr N, Markle JG, Fenollar F, Wong N, et al. IRF4 haploinsufficiency in a family with Whipple's disease. eLife. 2018 Mar 14;7.

117. Workowski KA, Bolan GA, Centers for Disease Control and Prevention. Sexually transmitted diseases treatment guidelines, 2015. MMWR Recomm Rep Morb Mortal Wkly Rep Recomm Rep. 2015 Jun 5;64(RR-03):1-137.

118. Ghanem KG. Management of Adult Syphilis: Key Questions to Inform the 2015 Centers for Disease Control and Prevention Sexually Transmitted Diseases Treatment Guidelines: Table 1. Clin Infect Dis. 2015 Dec 15;61(suppl 8):S818-36.

119. Getahun H, Matteelli A, Abubakar I, Aziz MA, Baddeley A, Barreira D, et al. Management of latent Mycobacterium tuberculosis infection: WHO guidelines for low tuberculosis burden countries. Eur Respir J. 2015 Dec;46(6):1563-76. 
Table 1. Evidence of bacterial survival without clinical symptoms in humans

Tableau 1. Données démontrant la survie bactérienne sans symptôme clinique chez l'homme

\begin{tabular}{|c|c|c|c|c|}
\hline Bacteria & Presentations & Site of latency & Cells & $\begin{array}{l}\text { Factor favoring } \\
\text { reactivation }\end{array}$ \\
\hline $\begin{array}{l}\text { Bartonella } \\
\text { henselae }\end{array}$ & $\begin{array}{l}\text { Asymptomatic } \\
\text { bacteremia }\end{array}$ & $\begin{array}{l}\text { Blood, } \\
\text { endothelium }\end{array}$ & $\begin{array}{l}\text { Erythrocytes } \\
\text { Endothelial cells }\end{array}$ & Immunosuppression \\
\hline $\begin{array}{l}\text { Tropheryma } \\
\text { whipplei }\end{array}$ & $\begin{array}{l}\text { Asymptomatic } \\
\text { carriers }\end{array}$ & Unknown & Macrophages & Immunosuppression \\
\hline $\begin{array}{l}\text { Treponema } \\
\text { pallidum }\end{array}$ & $\begin{array}{l}\text { Recurrence in the } \\
\text { secondary and } \\
\text { tertiary stages }\end{array}$ & $\begin{array}{l}\text { Lymph nodes } \\
\text { Central nervous } \\
\text { system }\end{array}$ & Unknown & $\begin{array}{l}\text { Immunosuppression } \\
\text { Congenital syphilis }\end{array}$ \\
\hline $\begin{array}{l}\text { Borrelia } \\
\text { burgdorferi }\end{array}$ & $\begin{array}{l}\text { Recurrence in the } \\
\text { secondary and } \\
\text { tertiary stages }\end{array}$ & Unknown & Unknown & None \\
\hline $\begin{array}{l}\text { Mycobacterium } \\
\text { tuberculosis }\end{array}$ & $\begin{array}{l}\text { Latent } \\
\text { tuberculosis } \\
\text { Recurrence }\end{array}$ & Granuloma & $\begin{array}{l}\text { Macrophages } \\
\text { Pneumocytes } \\
\text { Fibroblasts } \\
\text { Endothelial cells } \\
\text { Adipocytes }\end{array}$ & Immunosuppression \\
\hline Coxiella burnetii & Recurrence & $\begin{array}{l}\text { Placenta } \\
\text { Lymph nodes } \\
\text { Bone marrow }\end{array}$ & Macrophages & $\begin{array}{l}\text { Immunosuppression } \\
\text { Pregnancy }\end{array}$ \\
\hline $\begin{array}{l}\text { Staphylococcus } \\
\text { aureus }\end{array}$ & Recurrence & $\begin{array}{l}\text { Blood } \\
\text { Bone } \\
\text { Joint } \\
\text { Catheter } \\
\text { Heart } \\
\text { Respiratory tract }\end{array}$ & $\begin{array}{l}\text { Epithelial cells } \\
\text { Endothelial cells } \\
\text { Fibroblasts } \\
\text { Keratinocytes } \\
\text { Osteoblasts }\end{array}$ & Unknown \\
\hline Brucella abortus & None & Unknown & Unknown & Unknown \\
\hline $\begin{array}{l}\text { Rickettsia } \\
\text { prowazekii }\end{array}$ & $\begin{array}{l}\text { Brill-Zinsser } \\
\text { recurrence }\end{array}$ & Lymph nodes & Endothelial cells & Unknown \\
\hline
\end{tabular}


Table 2. Treatment recommendation for latent infection in adults

Tableau 2. Recommandations thérapeutiques en cas d'infection latente chez l'adulte

\begin{tabular}{|c|c|c|}
\hline Infection & CDC recommendations & Treatment \\
\hline Latent $M$. tuberculosis infection & $\begin{array}{l}\text { People with a positive IGRA result or a TST reaction of } 5 \text { or more millimeters } \\
\text { - } \quad \text { HIV-infected persons } \\
\text { - } \quad \text { Recent contacts of a TB case } \\
\text { - Persons with fibrotic changes on chest radiograph consistent with old TB } \\
\text { - } \quad \text { Organ transplant recipients } \\
\text { Persons who are immunosuppressed for other reasons (e.g., taking the equivalent of } \\
\text { People with a positive IGRA result or a TST reaction of } 10 \text { or more millimeters } \\
\text { - } \quad \text { Persons from high-prevalence countries } \\
\text { - } \quad \text { Injection drug users } \\
\text { Residents and employees of high-risk congregate settings (e.g., correctional facilities, } \\
\text { nursing homes, homeless shelters, hospitals, and other health care facilities) } \\
\text { - Mycobacteriology laboratory personnel } \\
\text { Children under } 4 \text { years of age, or children and adolescents exposed to adults in high- } \\
\text { risk categories }\end{array}$ & $\begin{array}{l}\text { Isoniazid daily or twice weekly for } 9 \\
\text { months } \\
\text { Isoniazid plus rifapentine once } \\
\text { weekly for } 12 \text { weeks } \\
\text { Rifampin (or rifabutin) daily for } 4 \\
\text { months }\end{array}$ \\
\hline Latent Treponema pallidum infection & $\begin{array}{l}\text { Latent syphilis is defined as syphilis characterized by seroreactivity without other } \\
\text { evidence of primary, secondary, or tertiary disease. } \\
\text { - Early latent syphilis: during the year preceding the diagnosis, they had } \\
\text { 1) a documented seroconversion or a sustained (>2 week) fourfold or greater } \\
\text { increase in nontreponemal test titers; } \\
\text { 2) unequivocal symptoms of primary or secondary syphilis; } \\
\text { or 3) a sex partner documented to have primary, secondary, or early latent } \\
\text { syphilis. } \\
\text { In addition, for persons with reactive nontreponemal and treponemal tests } \\
\text { whose only possible exposure occurred during the previous } 12 \text { months, early } \\
\text { latent syphilis can be assumed. }\end{array}$ & $\begin{array}{l}\text { Early latent syphilis } \\
\text { Benzathine penicillin G } 2.4 \text { million } \\
\text { units IM in a single dose } \\
\text { Late latent syphilis or latent syphilis } \\
\text { of unknown duration } \\
\text { Benzathine penicillin G } 7.2 \text { million } \\
\text { units total, administered as } 3 \text { doses of } \\
2.4 \text { million units IM each at } 1 \text {-week } \\
\text { intervals }\end{array}$ \\
\hline
\end{tabular}




\begin{tabular}{|l|l|l|}
\hline & $\begin{array}{l}- \text { Late latent syphilis or latent syphilis of unknown duration } \\
\text { In the absence of these conditions, an asymptomatic person should be considered to } \\
\text { have latent syphilis. }\end{array}$ & \\
\hline
\end{tabular}

IGRA: inter feron-gamma release assays; TST: tuberculin skin test; HIV: human immunodeficiency virus; TB: tuberculosis; TNF: tumor necrosis factor. 